\title{
Borvendég János professzor kapta a 2019. évi Hőgyes Endre-díjat
}

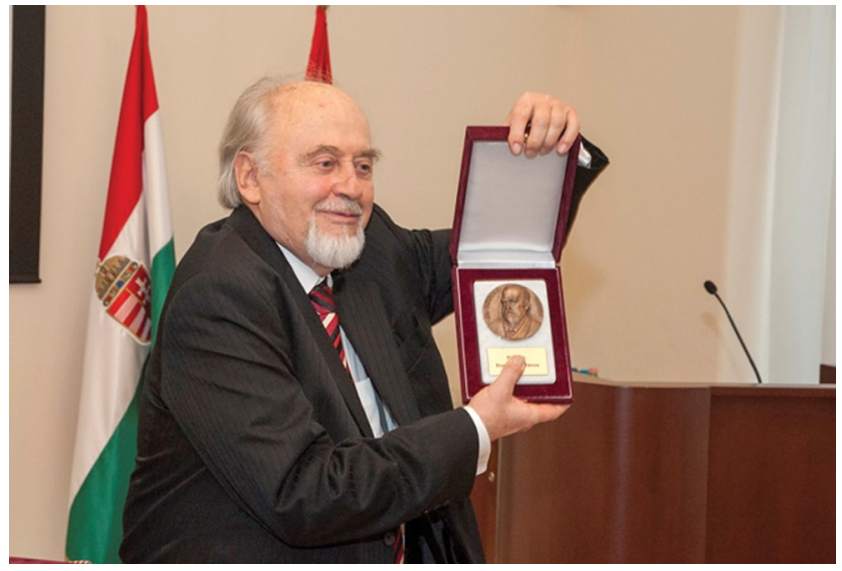

1. ábra | Borvendég János professzor a Hőgyes Endre-éremmel

Hőgyes Endre (1847-1906), a nagy magyar orvos tagja volt az Országos Közegészségügyi Tanácsnak, melynek utóda, az Egészségügyi Tudományos Tanács 1961-ben róla elnevezett emlékérmet és díjat alapított. Eddig minden évben a kutatásban és orvosetikában kiemelkedó tudós személyiségnek adományozták az elismerést. A 2019. évi Hőgyes Endre-díjat Dr. Borvendég János klinikofarmakológus-professzor kapta. Az átadási ünnepségre az Országos Reumatológiai és Fizioterápiás Intézet (ORFI) dísztermében, 2019. december 13-án került sor.

A vendéglátó, Dr. Poór Gyula - az ORFI fóigazgatója - megemlékezve Hőgyes Endréről, többek között rámutatott arra, hogy a hazai orvostudományban minden nagy orvosegyéniséget Semmelweis Ignáchoz szoktak mérni. Hőgyes Endre Semmelweis Ignáchoz hasonlóan az infektológia és a járványügy terén alkotott kiemelkedôt, és mindketten az európai úttörő́k közé tartoztak. Ahogy az aszepszis-antiszepszis terén beszélhetünk egy Semmelweis-Pasteur-Lister vonulatról, úgy a veszettség elleni védőoltás tekintetében Hőgyes Endre méltó felfedezőtársa volt Pasteurnek, hiszen a vakcinát a mai napig az ő hígításos módszerével állítják elő. Ugyanakkor Hőgyes Endre munkássága sokkal szerteágazóbb volt Semmelweisénél, akinek rövid élete folyamatos szakmai és emberi küzdelmekkel telt el. Hőgyes Endre már egy nyugodtabb korszakban, a Monarchiában alkothatott, és a fertőző betegségeken (a veszettség mellett a kolera, lépfene) túlmenóen az orvoslás számos területén volt meghatározó a munkássága. A vesekeringés tanulmányo- zásával a későbbi Korányi-iskola előfutára volt. Az 1870es években Bell felfedezését követően már egy éven belül hallásvizsgálatokra használta a telefont, és a Nobel-díjas Békésy György előtt elindította a hazai audiometriás vizsgálatokat. De tanulmányozta a C-vitamin jótékony hatását és számos alkaloidát is, megalapozva az ez irányú gyógyszerkutatásokat. Jelentôs hazai és külhoni publikációs tevékenységét széles körü ismeretterjesztéssel egészítette ki, mind kolozsvári, mind fővárosi éveiben. Most, hogy az utóbbi években sikerei révén az Orvosi Hetilap küldetése felértékelődött, érdemes megemlíteni, hogy 1886-tól haláláig Hőgyes Endre a lap főszerkesztôje volt.

Poór Gyula professzor szerint az idei díjazott Borvendég János professzor nemcsak a gyógyszerkutatásban alkotott maradandót, hanem a zenélés müvészetében is. Az ő magas moralitású személyét a rómaiak vir integernek vagy pir probatusnak nevezték volna, vagyis kétezer évvel ezelőtt az oltár szolgálatára is alkalmasnak találták volna. Az ő mindnyájunk számára követendő életútjának méltó megkoronázása a Hőgyes Endre-emlékérem.

Az emlékérmet Szigeti Szabolcs helyettes államtitkár adta át, majd Dr. Mandl József professzor, az Egészségügyi Tudományos Tanács elnöke többek között rámutatott arra, hogy a magyar klinikofarmakológia bővelkedett és bővelkedik jelentős, kiváló képességű személyiségekben, de olyan jellegú és ilyen módon megalapozott pályát, mint Borvendég professzor, senki nem futott be. Borvendég János életútja felöleli mind az experimentális kutatómunkát, mind a klinikumot, mind a magyar és a nemzetközi szintú hatósági szakmai és szakmai-etikai tevékenységet, ezért munkásságából adódóan nagyon sok szemmel képes rálátni a dolgokra. Karakterének és hitelességének titka mindenekelőtt az egyedülálló felkészültség mellett az örülni tudás képessége, az alkotásvágy, a szuggesztív érvelni tudás és a választékos kifejezőkészség. Alkotásvágyának múvészi kifejezése az orgonajátéka, amely nagyon sok embert szólított meg személyes emlékeket nyújtva.

Borvendég János az előadásában elsősorban szakmai pályafutásáról beszélt. Egészítsük ezt ki néhány fontos életrajzi adattal. Budapesten született 1935. június 25-én. Édesapja, Borvendég János gépészmérnök volt, édesanyja, Csermák Etelka tanítóképzőt végzett, családjának szentelte életét. Felmenői között találjuk Dr. Borvendég 
Ferencet, aki 1931-től 1934-ig Budapest alpolgármestere volt, majd 1934-ben fópolgármesterré választották. Testvérei: Béla (Ybl-díjas és Kossuth-díjas építész), Ilona (vegyészmérnök). 1962-ben nősült, felesége, Rétai Margit olajmérnök. Gyermekük, János Sebestyén (1968, belgyógyász, családorvos) négy unokával (Balázs, Borbála, Mátyás, Gergely) ajándékozta meg őket.

Borvendég János az Árpád Gimnáziumban tanult (1949-1953); summa cum laude minősítéssel 1959-ben szerzett orvosdoktori diplomát a Budapesti Orvostudományi Egyetemen és 2004-ben egészségügyi jogi oklevelet az Eötvös Loránd Tudományegyetemen. Szakképesítései: laboratóriumi vizsgálatok, belgyógyászat, klinikai farmakológia. Kandidátusi értekezését 1984-ben védte meg, 1997-ben habilitálták. Orvosi diplomájával 1959-ben Ózdon, a városi kórházban kezdte belgyógyászati gyakorlatát, majd 1962 és 1965 között a fóvárosi László Kórházban, 1965-tól 1971-ig pedig Szegeden, az I. Belgyógyászati Klinikán tanult és dolgozott. Tanulmányutak: Rotunda Hospital, Dublin (1968-1969), Max Planck Institute, Göttingen (1975) és Karolinska Institutet, Stockholm (1982).

A budapesti Gyógyszerkutató Intézet 1971-ben kérte fel endokrinológiai laboratórium létrehozására és az orvosi osztály vezetésére. Feladata az intézet által előállított új gyógyszerek (Zitostop, Lycurim, Tisasen stb.) klinikai vizsgálatának megszervezése volt. Az új endokrinológiai kutatólaboratóriumban anabolikus szteroidokkal, a növekedési hormonnal és fragmenseivel, az LHRH/TRH 'releasing' hormonok és a prolaktin elválasztását gátló szerek, antiösztrogének (Panomifen) komplex farmakológiai vizsgálatával foglalkozott. Javaslatot tett többek között a nyugaton már forgalmazott és bevált készítmények (cimetidin, naproxén, klórhexetidin) hazai adaptálására. Ebben az időben találkozott először a kialakulóban lévő klinikai farmakológia elméleti és gyakorlati kérdéseivel. Elsőként alkalmazott kettős vak-, kontrollált, randomizált klinikai vizsgálatot a Tobanum ${ }^{\circledR}$ (kloranolol) gyógyszer esetében. Ez a módszer abban az időben Magyarországon forradalmi újításnak számított.

Meghívásra 1982-ben az Országos Gyógyszerészeti Intézetben az orvosbiológiai főosztály vezetőjeként, majd az intézet fooigazgató-helyetteseként folytatta pályafutását. (2002-tôl az intézet fótanácsadója.) Főosztályvezetóként megszervezte az újonnan létesített orvosbiológiai főosztály biológiai minősítő, farmakológiai és klinikai osztályait. Ez utóbbinak feladata a klinikai vizsgálatok engedélyezése és a törzskönyvezésre benyújtott új gyógyszerek vizsgálati eredményeinek értékelése volt.

Az Országos Gyógyszerészeti Intézet 1970-től az Orvostovábbképző Intézetben önálló tanszékkel rendelkezett. A tanszék elsősorban a gyógyszerészek szakképzésében (gyógyszerellátás, kórház-klinikai/ipari szakgyógyszerészet, majd 1972-től, hatástan, toxikológia, gyógyszerkölcsönhatás oktatása) vett részt. Borvendég János itt kapott először docensi, majd egyetemi tanári kinevezést. Az intézmény megszünése után (2002) egye- temi tanár a Semmelweis Egyetemen, speciálkollégiumot tartott az ELTE Szerves Kémiai Tanszékén (19832017). Itt 2003-ban címzetes egyetemi tanári címet kapott.

A GCP (good clinical praxis - helyes klinikai gyakorlat) lelkes terjesztője; 1993-tól a GCP-tanfolyam elvégzését hazánkban kötelezővé tették a klinikai gyógyszervizsgálatokban részt vevő orvosok számára. A kezdetektől fogva az országos akkreditált tanfolyamok állandó előadója. Részt vállalt a klinikai farmakológus szakorvosjelöltek képzésében is. A Magyar Pszichofarmakológusok Társasága által évente megrendezett konferenciákon 2000 és 2016 között a pszichofarmakonokról rendszeresen vezetett kerekasztal-megbeszéléseket.

Meghívott előadóként külföldön is részt vett a klinikai vizsgálatokat értékelő szakemberek képzésében (Róma, Bécs). Előadásokat tartott nemzetközi kongresszusokon (London, 1976; Firenze, 2000; Orlando, 2006; Budapest, 2011).

Az Országos Gyógyszerészeti Intézetben (OGYI) ugyancsak fontos feladata volt többek között több nemzetközi bizottságban való részvétel. Ezek közül említésre méltó a KGST-országokban fejlesztett új gyógyszerek farmakológiai, toxikológiai és klinikai vizsgálatainak, illetve az ezen adatokat tartalmazó dokumentáció követelményeinek harmonizálása az OGYI felügyelete alatt. Fontos szerepe volt abban, hogy a törzskönyvezési elvárásokkal megakadályozta az aluldokumentált készítmények forgalomba hozatalát. Magyarország számára a bizottság tevékenysége fontos volt, hiszen Magyarország volt a legfontosabb gyógyszer-előállító és -exportáló a régióban. 1983 és 1990 között folyamatosan részt vett a European Free Trade Association Pharmaceutical Evaluation Report Scheme bizottságában, a volt szocialista országok közül egyedüliként. A WHO International Drug Monitoring Centre (Uppsala Monitoring Centre, UMC) rendezvényein rendszeresen részt vett Európában, de Tuniszban, a Dél-afrikai Unióban, Indiában, Ausztráliában és Kanadában is. A gyógyszermellékhatások bejelentésének száma abban az időben Magyarországon meglehetősen szerény volt, de a bizottság adatbázisa és a konferenciákon elhangzottak alapján az OGYI számos fontos információhoz jutott.

Jelentős a képviselete az EMA (European Medicine Agency), a CHMP (Committee for Medicinal Products for Human Use) és a COMP (Committee for Orphan Medicinal Products) nemzetközi bizottságokban. Ezekben a bizottságokban értékelik az újonnan elóállított gyógyszerkészítmények törzskönyvezési dokumentációját, és pozitív esetben javasolják az Európai Bizottságnak a készítmény törzskönyvezését.

Megalakulásától (2003) fogva az OGYI képviselője, és alelnök az Egészségügyi Tudományos Tanács Klinikai Farmakológiai és Etikai Bizottságában. Több mint 50 tudományos közlemény szerzője, társszerzője. Kézikönyvek szerkesztője, könyvfejezetek szerzője: Klinikai vizsgálatok GCP szerint (1996); Gyógyszerkompendi- 
um 2007/2008. Formula Normales VII. Orvosi kiadás (2003); Panasz Magyarázat Gyógyszer 2000/2003. A 30000 példányban havonta megjelenő Gyógyszereinknek, az OGYI hivatalos lapjának hosszú éveken át volt rendkívüli munkabírású főszerkesztője (1991-2002).

A népszerü Gyógyszereink főszerkesztőjeként részt vett az ISDB (International Society of Drug Bulletins) Independent Drug Bulletins nemzetközi csoportjának munkájában (1983-2002). Kampányt folytattak a megtévesztő gyógyszerhirdetések ellen, igyekeztek átláthatóságot biztosítani az új gyógyszerek hatósági értékelésében, a gyógyszermellékhatások feltárásában és a nem publikált klinikai vizsgálatok nyilvánossá tételében.

Vezetőségi tagja a Magyar Kísérletes és Klinikai Farmakológiai Társaságnak, 2001-ben Issekutz-díjjal tüntették ki.

Borvendég János professzor korát meghazudtoló szellemi frissességben, remek humorral és önkritikával füszerezett élvezetes előadást tartott a nagyszámú hallgatóság előtt pályafutásáról, eredményeiről és kudarcairól, meg- adva ezzel az ünnepség őszinte, közvetlen, családi hangulatát. A szavakkal és a kifejezésekkel úgy bánt az előadásában, mintha orgonán játszott volna: a sikerek elbeszélésekor a magasabb hangokat adó sípokat szólaltatta meg a billentyúsorokon, a csalódott részeknél pedig a pedálsor komor hangjait taposta a lábával, magával ragadva tanítványainak, munkatársainak és tisztelőinek lankadatlan figyelmét. Talán a szúnni nem akaró taps után hiányzott egy zongorajáték (a szervezőkön nem múlt, mert egy zongorát is elhelyeztek a színpadon), hiszen Borvendég professzor gyermekkorától zongorázik és orgonál. Több alkalommal adott (és jelenleg is ad) orgonakoncertet a budapesti Szent István-bazilikában és vidéki városok templomaiban is. Kedvenc zeneszerzői elsősorban: Johann Sebastian Bach, Ludwig van Beethoven, Johannes Brahms, César Franck és Liszt Ferenc. Nekünk pedig Ô a kedvenc klinikofarmakológus orgonistánk.

Papp Zoltán dr.

"Solet sequi laus, cum viam fecit labor." (Hol kemény munka tör utat, a nyomában dicsőség jár.) 